\title{
Uniform Application of Law in Ethiopia: Effects of Cassation Decisions of the Federal Supreme Court
}

\author{
Hussein Ahmed Tura \\ Ambo University, School of Law, Ambo, Ethiopia
}

\begin{abstract}
The Ethiopian legal system has transplanted substantial elements from both Continental Law and Common Law legal systems. While the legal system is characterized by its reception of substantial rules from the Continental Law Legal System, there are some concepts transplanted from the Common Law legal system particularly incorporated in the procedural laws. Moreover, under Proclamation No. 454/2005, the interpretation of laws by the Cassation Division of the Federal Supreme Court (hereinafter Cassation Division) is made to have binding authority on all lower courts at all levels in the entire country. Although the Proclamation seems to introduce the doctrine of precedent, there is a debate as to whether what is introduced under the Proclamation amounts to a precedent system or not. Moreover, it is not expressly given whether judicial organs other than regular courts such as administrative agencies or tribunals, religious and customary courts are bound by the decision of the Cassation Division. The Proclamation also does not provide for the effects of overruling and preconditions to overrule previous decisions of the Cassation Division. The purpose of this article is to critically analyze the legal effects of the binding interpretation of law given at cassation by the Federal Supreme Court in the Ethiopian legal system.
\end{abstract}

\section{Keywords}

Binding precedent - judicial overruling - ratio decidendi - declaratory theory - cassation power - Federal Supreme Court - Ethiopia

\footnotetext{
* E-mail: hatura7@mail.com. The author is Lecturer in Law at Ambo University, School of Law.
} 
The Federal Democratic Republic of Ethiopia (FDRE) Constitution establishes a dual court structure. ${ }^{1}$ It also stipulates that the 'judicial powers, both at Federal and State levels, are vested in the courts; ${ }^{2}$ and there are three-tier court structures both at the Federal and State levels having their own jurisdictions. ${ }^{3}$ Moreover, the Federal Supreme Court is entrusted with the highest and final judicial power over Federal matters; and the State Supreme Courts have the highest and final judicial power over State matters. ${ }^{4}$ The Federal Supreme Court also has a power of cassation over any final court decision containing a basic error of law. ${ }^{5}$ Although the Constitution also gives a power of cassation to the State Supreme Court over any final court decision on State matters which contains a basic error of law, ${ }^{6}$ the Cassation Division is reviewing final decisions of a State Supreme Court which gives rise to cassation over cassation, a dubious practice in the federal court system of Ethiopia. ${ }^{7}$ The practice of cassation over cassation in turn became one of the contentious issues, which attracted a heated debate among legal scholars and practitioners in Ethiopia on its compatibility with the overall federal system and its constitutionality. ${ }^{8}$

Furthermore, decisions of the Cassation Division, rendered by no less than five judges, are binding on all federal and states courts at all levels. ${ }^{9}$ The law and the practice, thus, seem to introduce the doctrine of binding precedent whereby the decisions of superior courts are normally followed by lower courts. On the other hand, Ethiopia predominantly follows the continental legal system. Judges are duty bound to apply legislations and resort to interpretation is accepted only where there is an ambiguity with respect to the existing

1 See Fdre Constitution (1995), Proclamation No. 1/1995, Fed. Neg. Gaz., Chapter 9, Articles 78-81, which generally provide for structure and powers of courts.

2 Ibid., Article 79(1).

3 Ibid., Article 79(2) and (3). The federal court structure includes: Federal Supreme Court, Federal High Court and Federal First Instance Court. States also establish State Supreme, High and First-Instance Courts.

4 Ibid., Article $8 \mathrm{o}(1)$ and (2).

5 Ibid., Article 8o(3)(a).

6 Ibid., Article 8o(3)(b).

7 Federal Courts Establishment Proclamation (1996), Proclamation No. 25/1996, Fed. Neg. Gaz. Article 10.

8 M. Abdo, 'Review of Decisions of State Courts over State Matters by the Federal Supreme Court', 1 Mizan Law Review (2007), 60-74.

9 Proclamation No. 454/2005, Article 2. 
law. ${ }^{10}$ The introduction of binding precedent may also give rise to a question of legitimacy in light of the 'doctrine of separation of powers' under the FDRE Constitution. The law further empowers the Cassation Division to change its own previous decisions without further rules on the effects of overruling and preconditions to overrule. Moreover, the usefulness of binding precedents can only be realized if the binding portion of the judgment can be readily isolated from the law report. However, since following a binding precedent is a new development in Ethiopia, judges have very limited knowledge and skill to find a ratio decidendi of a case (binding part of decision).

Therefore, this article analyses some theoretical and practical issues surrounding the binding interpretations of law rendered by the Cassation Division in Ethiopia. It is organized into six sections. The second section reviews literature on the meaning, essence, advantages and disadvantages of the doctrine of precedent. The third section presents an overview of the peculiar features of the Ethiopian legal system. The fourth section explores the historical introduction of precedent into the Ethiopian legal system. The fifth section critically reviews and analyses the effects of binding interpretation of law rendered by the Cassation Division. Particularly, an effect of binding precedent is critically analyzed in light of the doctrine of 'separation of powers', judicial overruling, and on how to find the ratio decidendi of binding decisions of the Cassation Division. The last section concludes on some implicatisons of the study.

\section{Doctrine of Precedent: An Overview}

\subsection{Meaning and Essence of Precedent}

Precedent has been given a variety of titles, which reflect the interrelated views. For instance, 'judge made law', 'case law', 'judicial law', or in Latin 'stare decisis' (let the decision stand) are among the terms used by different legal writers in order to refer to precedent. ${ }^{11}$ In the common law, precedent is a principle or rule established in a case that a court or other judicial body may apply when deciding subsequent cases with similar issues or facts. ${ }^{12}$ Black's Law dictionary also defines 'precedent' as 'an already decided decision which furnishes the basis for later cases involving similar facts and issues. ${ }^{\prime 3} \mathrm{~A}$ precedent that must

\footnotetext{
10 See, for instance, Articles 1714(2) and 1733 of the Civil Code of Ethiopia.

11 A.W.B. Simpson, Legal Theory and Legal History: Essays on the Common Law (Continuum, London, 1987), p. 359 .

12 P. Harris, An Introduction to Law, $5^{\text {th }}$ edn (Butterworths, London, 1997), p. 188.

13 B. Garner, Black's Law Dictionary, 7 th edn (West Group, St. Paul, MN, 1999).
} 
be applied or followed is known as binding (mandatory) precedent, which is described as follows:

Given a determination as to the governing jurisdiction, a court is 'bound' to follow a precedent of that jurisdiction only if it is directly on point. In the strongest sense, 'directly on point' means that: (1) the question resolved in the precedent case is the same as the question to be resolved in the pending case; $(2)$ resolution of that question was necessary to the disposition of the precedent case; (3) the significant facts of the precedent in the pending case; and (4) no additional facts appear in the pending case that might be treated as significant. ${ }^{14}$

The United States Court of Appeals for the third circuit has also stated:

A judicial precedent attaches a specific legal consequence to a detailed set of facts in an adjudicated case or judicial decision, which is then considered as furnishing the rule for the determination of the subsequent case involving identical or similar material facts and arising in the same court or a lower court in the judicial hierarchy. ${ }^{15}$

Thus, precedent is a legal principle, created by a court decision, which provides an example or authority for judges deciding similar issues later. The principle of binding judicial precedent is fundamental to the common law legal tradition, which is based on the accumulation of past judicial decisions. ${ }^{16}$ In this legal system, binding precedent signifies that decisions are followed due to the reason that judges feel an obligation to do so irrespective of their views on the merits of the precedent. ${ }^{17}$ Precedent has self-generating aspect in that 'appropriate references for justifying legal decisions are prior legal decisions of the same order; and every decision serves as reference for future decisions. ${ }^{18}$ A judicial decision has two purposes in the common law. First, it is used to establish precedent so that like cases arising in the future will be decided likely.

14 M. Rombauer, Legal Problem Solving: Analysis, Research and Writing, 3rd edn (West Publishing, St. Paul, MN, 1978), at 22-23.

15 Allegheny General Hospital vs. NLRB, 6o8 F.2d, 965, 969-970 (3rd Circuit, 1979).

16 C. Stychin, Legal Method: Text and Materials, 1st edn (Sweet \& Maxwell, London, 1999), at 100.

$17 \quad$ Ibid., at 99 .

18 E. Hanks, M.E. Herz and S.S. Nemerson, Elements of Law (Anderson Publishing, Cincinnati, OH, 1994), p. 4. 
Second, it serves to dispose a controversy between parties in order to prevent a re-litigation on the same issue in the future. ${ }^{19}$

On the other hand, there is a case where early decisions of courts have only persuasive effect. ${ }^{20}$ In other words, a previous decision may carry a great weight so that a court may adopt it in deciding a present case. Thus, persuasive precedent can be defined as 'a precedent in which a judge is not obliged to follow but in fact s/he would hesitate to disregard.21 There are several factors that determine the degree of persuasiveness of a decision, inter alia including: the prominence of a court, the force of reasoning in a decision and similarity of issues, the date of a case, the existence of a dissenting opinion when the case was decided, circumstances in persuasive decision and a problem at hand..$^{22}$ As all judges are presumed to be equal; the prestige of a judge is no more considered. However, if a court is higher in hierarchy, its pronouncements will carry a great weight. ${ }^{23}$ The date of a case is also vital in determining the persuasiveness of a case due to the fact that if the case is a recent one, it accommodates the changed circumstances. Court's decision may contain a dissenting opinion of a judge. ${ }^{24}$ The existence of this type of opinion might reduce the weight given to the case. ${ }^{25}$

Despite the absence of a formal doctrine of precedent, there is strong tendency on part of the French courts to follow precedents, especially those of the higher courts. This tendency is based on the need to maintain professional dignity, avoid excessive or prolonged litigation, share time and attention to other matters where no precedent exists and more importantly to maintain uniformity of judicial decisions. ${ }^{26}$

Therefore, precedent is not only an element of the common law but also it is a feature of law in general. All legal systems in the contemporary world follow it to a greater or lesser extent.

\footnotetext{
19 Simpson, supra note 11, at 359.

20 I. McLeod and M. Cremona, Legal Method, 4th edn (Palgrave Macmillan, London, 2002), p. 122.

21 J. Adams and R. Brownsword, Understanding Law, 4th edn (Sweet \& Maxwell, London, 2006), p. 118.

22 E. Farnsworth, An Introduction to the Legal systems of the United States, 3rd edn (Oceana Publications, Dobbs Ferry, NY, 1996), p. 53.

23 T. Ingman, The English Legal Process, 6th edn (Blackstone, London, 1996), p. 295.

24 A dissenting opinion is 'an opinion of a judge who disagrees with the decision reached by the majority and refuses to join the court's decision', see Blacks Law, supra note 13.

25 J. Dernbatch, R.V. Singleton, C. Wharton, J. Ruhtenberg and C.J. Wasson, A Practical Guide to Legal Writing and Legal Method, 2nd edn (Fred B. Rothman, Littleton, Co, 1994), p. 36.

26 Farnsworth, supra note 22, at 117.
} 


\subsection{Justifications for and against the Application of Precedent \\ 2.2.1 The Justifications for Precedent}

There are various reasons for applying precedents. One of such reasons is certainty. Since deciding a single case amounts to deciding all subsequent similar cases, it gives certainty to the law. ${ }^{27}$ This in turn brings predictability in the law, which can be used as guidance to lawyers and judges faced with a similar situation. It also permits persons to order their affairs and come to settlements with certain amount of confidence. ${ }^{28}$ On the contrary, a code cannot necessarily provide for all future cases since it is incomplete. ${ }^{29}$ As the doctrine of precedent is comprehensive in its nature, it provides only for general principle of law, not for detailed rules. Thus, predictability of precedent can be used to remedy the defect of code to fully predict. ${ }^{30}$

The other justification for applying precedent is justice. As precedent treats similar cases similarly, all persons who come to courts will be treated equally. This will serve the interest of justice by bringing consistency in court decisions. ${ }^{31}$ Following precedent is also an important and a convenient timesaving device. It minimizes litigation. Thus, precedent is an efficient way to save judicial resources in judicial administration. ${ }^{32}$ It should, however, be stressed that the convenience of following precedent should not be allowed to degenerate into a mere mechanical exercise performed without any thought. Precedents should be used as 'stepping-stones' instead of as 'halting places.'33 Precedent is grounded upon actualities of litigation and reality of human conduct. It shows the detailed application of the law to various circumstances. Thus, precedent is pragmatic in character. It may enable courts to make the law adoptable to the new changes. ${ }^{34}$ Therefore, the law reform undertaken through judicial process will be swifter than parliamentary action would be. Unlike the codification, which is difficult to alter and adjust to the experience and custom of the community, the doctrine of precedent offers opportunity

\footnotetext{
27 Adams and Brownsword, supra note 21, at 294.

28 Ingman, supra note 23, at 39.

29 J. Farrar and A. Dugdale, Introduction to Legal Method, 3rd edn (Sweet \& Maxwell, London, 1999), p. 294.

$30 \quad$ Ibid.

31 Farnsworth, supra note 22, at 52.

32 W. Reynolds, Judicial Process in a Nutshell, 2nd edn (West Publishing, St. Paul, MN, 1991), p. 168.

33 Ingman, supra note 23, at 302.

34 R. Binns, Blackstone's Study Packs: English Legal Method: Includes Cases and Materials On CD-ROM, 3rd edn (Oxford University Press, Oxford, 2001), p. 22.
} 
for growth and legal developments. ${ }^{35}$ Furthermore, there is respect to earlier decisions under the doctrine of precedent. This shows a due respect for the wisdom and experience of prior generations of judges. Besides, it gives legitimacy for decision-making institutions. ${ }^{36,37}$

\subsubsection{Arguments against Doctrine of Precedent}

Despite the aforementioned advantages, precedent is criticized for its rigidity, complexity and injustice. Precedent is a flexible principle which presupposes a judge's discretion to lay down a rule she considers desirable in order to keep the law in step with changing social and economic conditions. Yet, a judge is not free where there is a binding precedent. In this manner, the alleged flexibility becomes rigidity. Besides, flexibility and certainty can not exist at the same time. A system that is flexible cannot at the same time be certain because no one can predict when and how legal development will take place. ${ }^{38}$ On the other hand, the advantage of certainty will also be lost when there are too many volumes of case reports, which is the characteristic of the law. ${ }^{39}$ On the other hand, in the codification system, the law is more systematic, compact and accessible to the public. Hence, the rigidity that is produced by the system of precedent can be avoided by codification. ${ }^{40}$ Furthermore, precedent is much complex to apply since the judges who need to apply it must determine the ratio decidendi of a case. ${ }^{41}$ It is difficult to pinpoint the appropriate a principle from previous decision to be followed.

Besides, under the doctrine of binding precedent, judges are obliged to follow precedents even though they know that it is unjust. ${ }^{42}$ This may in some instances limit the discretion enjoyed by the lower court judges. This in turn affects the decisional independency of judges. ${ }^{43}$ This means, lower court judges are not at liberty to decide, as they will be obliged to make sure that their decisions fit into the existing legal framework. ${ }^{44}$ Thus, precedent violates judicial or decisional independence, which may lead to inconsistency of decision since a lower court judges will sometimes seek to avoid a rule contained

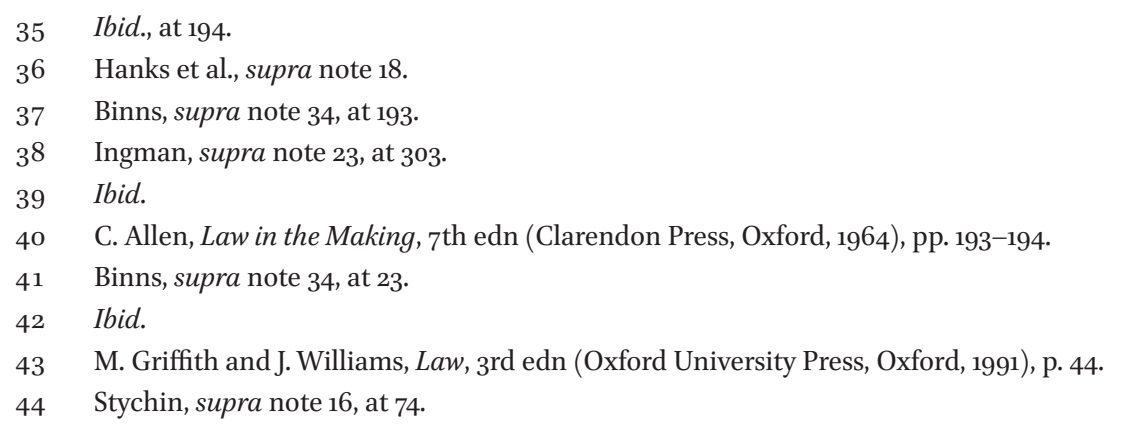


in an established precedent that would otherwise result in hardship in the case before him. ${ }^{45}$ In general, one may find for almost every advantage claimed for the doctrine of precedent a corresponding disadvantage. However, it does not mean that the disadvantages outweigh the advantages.

To understand the peculiar features of the Ethiopian law, it would be wise to start with the identification of its position in the major world legal families. The Romano-Germanic law was transplanted to Ethiopia mainly through the process of 'reception' rather than original contribution since Ethiopia was not colonized. ${ }^{46}$ The distinctive feature of this legal system has been that it had attached special importance to the enacted legislation, in the form of codes. Even though the country had its own civilization, ideologies and cultures, ways of thinking and acting, as well as her own indigenous institutions, it has accepted the Romano-Germanic law partly since the 15th century through Fetha Negast which was based on the Roman-Byzantine law. ${ }^{47}$ Later on, the country began the codification process, particularly, by codifying the Penal Code of 1930 and other six codes in the second half of the 2oth century. ${ }^{48}$ In fact, the reception and adoption of the western jurisprudence was selective; and it was not outright and complete reception. ${ }^{49}$

The country chose to design its laws predominantly after the continental law legal system based on several reasons. The first reason was its prior exposure to codification. Fewese Menfesawi and Fetha Negest were regarded as code. ${ }^{50}$ The 1930 Penal Code was another example. Besides, there were several statutes issued in the 1920 s, 1930 s and $1940{ }^{.51}$ Moreover, the country's experience under the Italian occupation for five years did not detach it from the code system, as Italy put in place a code referred to as 'Italiana Africa Orientale.52 The second

$45 \quad$ Ibid., at 65 .

46 A. Jambere, Legal History of Ethiopia, 1434-1974: Some Aspects of Substantive and Procedural Laws (Lit, Hamburg, 2000), p. 10.

$47 \quad$ Ibid.

$48 \quad$ Ibid., at 11.

49 Ibid., at 10.

50 M. Abdo, Legal History and Traditions (Justice System and Legal Research Institute, Addis Ababa, 2007), p. 189 .

$51 \quad$ Ibid.

$5^{2} \quad$ Ibid. 
factor for the decision under consideration was convenience and expense. The key personalities of the day thought that to transplant cases from England or the United States would be costly and most inconvenient while they assumed that codes could be transplanted with a greater ease. ${ }^{53}$ Furthermore, the same key personalities of the day had had sentimental attachment to France and French legal education. ${ }^{54}$ They liked the French approach to the modernization of laws. Besides, codes taken from France and Germany to other parts of the developing world were found to be successful. ${ }^{55}$ Thus, the justification was that if codes transplanted to countries similar in context to Ethiopia had already become a success, then there would be no reason for the same codes not to meet success in Ethiopia. ${ }^{56}$ Moreover, 'in making his decision to link Ethiopian codification to the system of Romano-Germanic law, Emperor Haile Sellassie I was guided in part by an instinctive desire to remain faithful to a venerated tradition, the allusion that he made to the Fetha Negest in an address inaugurating the work of the codification commission left no doubt in this regard. 57

Nevertheless, this does not mean that the Anglo-Saxon law was disregarded altogether. Although the major parts of the provisions of the 1957 Penal Code of Ethiopia were taken from the Romano-Germanic sources, some of its provisions were inspired by the Anglo-Saxon law. ${ }^{58}$ In addition, the Anglo-Saxon law inspired the procedural laws. ${ }^{59}$ In connection with the adoption of western legal principles by Ethiopia, Rene David pointed out that:

Ethiopia, apart from any European colonization, adopted codes of French inspiration in 1957 and 196o (Criminal, Civil and Commercial Codes). Civil and Criminal procedures are, however, contained in the codes of English inspiration. Only evolution will show whether Ethiopian and other laws of Black Africa are to be considered as one or several autonomies groups within the Romano-Germanic family. ${ }^{60}$

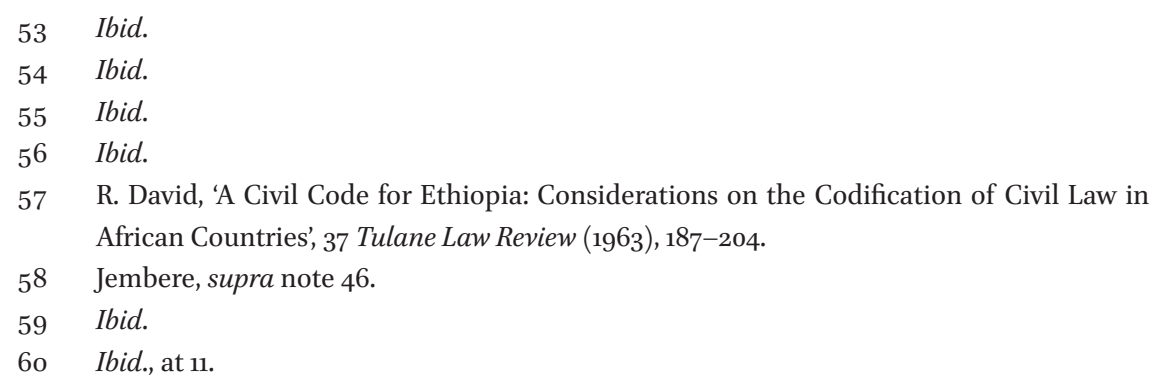


Therefore, in Ethiopia, similarly to states such as Quebec and Louisiana, the substantive codes follow the continental models while the procedural laws follow the Anglo-American traditions. ${ }^{61}$

On the other hand, the Ethiopian legal system did not leave out the long established customary law. ${ }^{62}$ Particularly, the country reserves a place for customary law under Article 3347(1) of the Civil Code for matters, which were not covered by the Code. It has also retained customary law concepts in the areas of family relationships, succession and other personal matters. ${ }^{63}$ In addition, Atse-ser'at was one of the sources of the modern codified laws of Ethiopia. ${ }^{64}$ Thus, Ethiopia may be described as a country where all legal systems converge. Because its reception of foreign law was selective, it has drawn the best from a variety of foreign sources that were suitable to be adopted in relation to its specific context; and these have rendered the system to have its own unique features.

It is very difficult to illustrate the development of legal concepts in various periods as historical events in the area of law have not been fully recorded in Ethiopia. Such challenge is also unavoidable with respect to a study of the development of precedent in the country. Despite such difficulty, however, there is evidence of a tradition that resembles precedent in the adjudication of cases in the country until 1942, which was known as the system of Atse-ser'at. ${ }^{65}$ Atseser'at literally means 'the law (work) of the sovereign.'66 At the time, the roof principle of law was litigation. ${ }^{67}$ The emperor was at the top of the hierarchy, and when he rendered a decision in National Court of Appeal, his ruling would be Atse-ser'at. ${ }^{68}$ This was due to the fact that the emperor was consid-

\footnotetext{
61 Anonymous, An Introduction to the Legal System of Ethiopia, (Faculty of Law, Haile Selassie I University, Unpublished, 1964), p. 2.

$62 \quad$ Ibid.

63 David, supra note 43, at 12, See also the FDRE Constitution, 1995, Article 34.

64 Jembere, supra note 46 , at 83 .

65 Ibid., at 95 .

66 Ibid.

67 It is to be noted that this system was not applied throughout the current Ethiopia. It was limited to the domain of politico-cultural of the Highland Kingdom, with its hierarchical structure.

Ibid.
} 
ered as the fountain of justice. Thus, a ruling made by him could be cited in future cases as a law in deciding cases of similar nature. ${ }^{69}$ Cases decided by the emperor, the chief justices or by the Ras Wenbers (higher officials) were followed by the judges in deciding analogous cases based on two grounds. The first ground was based on the old saying and consensus of the community, which holds that 'a case is further supported by a case as a thorn is pulled out by a thorn.' The second ground was that, as per Fetha Negest, the judge was expected to adjudicate cases based on his own conscience. 'His conscience' can be conceived broadly and could be interpreted to include previously decided cases. Consequently, judges were used to decide cases based on outstanding cases and judicial rulings. However, as Atse-ser'at was a traditional system, it is difficult to regard it as established typical rule of precedent.

After 1942, in the period when the country started to modernize its legal system through the process of codification, lower courts were not bound to follow the decisions of higher courts due to changes in procedural laws in the country. ${ }^{70}$ The attempt to incorporate precedent in the legal system was rejected on the basis of arguments of the key personalities during Haile Sellssie I regime who considered transplanting cases from England or the United States costly and most inconvenient, and who assumed that codes could be transplanted with greater ease.${ }^{71}$ Nevertheless, there is no a provision of the law which explicitly prohibits lower courts from following decisions rendered by the higher courts in deciding similar cases. ${ }^{72}$

Besides, the country enacted certain legislations, which accorded some places to precedent in different times in its legal system. For instance, Proclamation No. 195/1962 made the decisions of superior courts binding on all subordinate courts on matters of law. ${ }^{73}$ Nevertheless, court decisions were not officially published nor their status as precedent was practically certain at the time. ${ }^{74}$ This indicates that precedent in the common law sense was not employed in the country by Proclamation No. 195/1962. In a similar vein, the Proclamation enacted during the Transitional Government (i.e., Proc. No. 40/1993)

\footnotetext{
$69 \quad$ Ibid.

$70 \quad$ Ibid.

71 M. Abdo, supra note 50.

72 J. Vander linden, 'An Introduction to the Sources of Ethiopian Law', 3Journal of Ethiopian Law (1966), 227-255, at 246.

73 The Courts' Proclamation (1962), Proclamation No. 195, Article 15, Neg.Gaz, 22nd year, No. 7 .

74 Jembere, supra note 46.
} 
under Article 24(4) stated, "... an interpretation of law made by a division of the Central Supreme Court constructed by no less than five judges shall be binding." ${ }^{.5}$ Likewise, Proclamation No. 454/2005, which is the subject of analysis under this article, under Article 2(1) provides that "an interpretation of law by the Federal Supreme Court rendered by the Cassation Division with no less than five judges shall be binding on the federal as well as regional courts at all levels."

It is worth noting that the aforementioned three proclamations have common features in that all of them introduce the common law concept of precedent into the Ethiopian legal system in spite of differences in the extent to which the doctrine is introduced under each of them. Further, all of them bind lower courts as to the decision on matter of law. In other words, they do not bind lower courts as to the facts of the case.

As long as the degree to which precedent is introduced under these legislations is concerned, Proclamation No. 195/1962 is broader than the other two legislations because it stipulates that all the lower courts are bound by the decisions of the higher courts although its practical application was in question. The second and the third proclamations referred only to a Cassation Division within Central or Federal Supreme Court, which bind all courts. In other words, they limit themselves to specific division unlike the common law system where lower courts are generally bound by the decisions of higher courts according to their hierarchy.

Regarding the history of case reporting in Ethiopia, again, there is a limitation of direct source of information. There is only some trace of judgments recorded by travelers and historians. ${ }^{76}$ As well, the individual judgments recorded by travelers and historians do not form a comprehensive picture of what case law was in the country. ${ }^{77}$ Emperor Menelik II ordered decisions of judges to be recorded in register of judgments only in $1908 .{ }^{78}$ Moreover, the Digest of Ethiopian case law was prepared and published in the 1950s, which was initiated by emperor Haile Sellassie I instructions with a view to facilitate work of the Codification Commission that was established to modernize the Ethiopian legal system in 1950 s. $^{79}$ As a result, the Commission compiled cases previously decided in what is known as the Ancient Ethiopian Book of

\footnotetext{
75 A Proclamation to provide for the Establishment of Courts of Central Transitional Government (1993), Article 24(4), Proclamation No. 40/1993, Neg. Gaz, 52nd year, No. 25.

76 Jembere, supra note 46 , at 84 .

77 Vanderlinden, supra note 72 , at 247.

78 Supra note 61.

79 Jambere, supra note 46.
} 
Judgments, which contained a set of five volumes incorporating more than seven thousand decisions ranging over an unknown period since $1935{ }^{80}$ This digest consists of material of high value in the Ethiopian case reporting system.

For the period after the digest was published, although the bulk of decisions have gradually increased, the only way to learn about the decisions was to go through the archives of the various courts. ${ }^{81}$ Fortunately, some cases have been published in the Journal of Ethiopian Law. ${ }^{82}$ It was intended to be a temporal source of significant court decisions for their valuable contribution to the law profession and law students. ${ }^{83}$ More importantly, recently as authorized under Article 2(1) of Proclamation No. 454/2005, the Federal Supreme Court has started to publish and distribute decisions rendered by the Cassation Division. So far the Supreme Court has published 14 volumes involving interpretation of laws on cases containing basic error of the law. This can be taken as a good step towards improving the existing case reporting system in the country as they are binding on all courts at all levels (federal and state). It is also believed to add one element in the development of the Ethiopian legal system.

\section{Effects of the Cassation Decisions of the Federal Supreme Court} of Ethiopia

In the introductory section, we saw that the Federal Supreme Court of Ethiopia has a power of cassation over any final decision containing a basic error of law, including those decisions rendered by Cassation Division of the State Supreme Court. Moreover, the decisions of the Cassation Division rendered by not less than five judges are legally binding on all courts at all levels in Ethiopia pursuant to Proclamation No. 454/2005. In the following sub-sections, this article assesses the objectives sought by introduction of binding precedent, the nature of precedent introduced and its effects on doctrine of separation of powers, the effects of retrospective judicial overruling by the Cassation Division on the legal system in general and financial arrangements of parties to the overruled cases in particular; and how to find ratio decidendi of a case (binding part of a decision).

\footnotetext{
$80 \quad$ Ibid.

$81 \quad$ Supra note 61.

82 Vanderlinden, supra note 72 , at 249.

83 Ibid.
} 


\subsection{Rationales for Following Binding Interpretations of Law}

Proclamation No. 454/2005, which introduces binding precedent into the present legal framework of Ethiopia, aims at achieving uniform application of law, equal treatment of parties to a case, predictability and certainty of law in the country.

One may find differing interpretation of laws rendered by different courts in Ethiopia. The Cassation Division is thus established to bring uniform interpretation and application of laws in the country. ${ }^{84}$ Furthermore, to achieve this purpose, the Cassation Division's decisions are made to have a binding authority on the regional and federal courts at all levels. ${ }^{85}$ The second purpose sought to be achieved by the Proclamation is the enforcement of a constitutional right of every person to be treated equally before the law. ${ }^{86}$ If courts interpret the law differently, the litigants could be treated differently; and they will be subjected to unnecessary expenses and inconvenience. However, if the Cassation Division can bind lower courts ${ }^{87}$ so that they will interpret and apply the law uniformly by taking its position in the interpretation of the law, the litigants before the lower courts would be treated alike and their constitutional right under Article 25 of the FDRE Constitution, equal protection before the law would be enforced. Adherence to this principle tends not only to guarantee equality in administration of justice but also it creates public impression that courts do administer justice equally so that the public confidence on the legal system will be enhanced.

Moreover, bringing interpretation of the law will make the Ethiopian legal system more certain and predictable. ${ }^{88}$ Since the official declaration of the law and attitude of the Cassation Division will be taken as determinate and reliable indications of the course to be considered by lower courts in future cases, the society transacts with certainty on what the consequence of their transaction will be. It can also reduce the workload of the Cassation Division due to the fact that once it has pronounced a binding decision on a legal issue, a case with similar legal issue may not be brought before it again as the lower courts must decide on the basis of the analogous decision rendered by it. Consequently, it will save the time and resources of the Cassation Division and enable it to function more efficiently. Moreover, it assists the Division to concentrate on

\footnotetext{
84 The Minutes of the Constitutional Assembly of the FDRE Constitution, No. 5 (Dec 1994), at 32 .

85 Proclamation No. 454/2005, Article 2(1).

86 Commentary on Federal Courts' (amendment) Proclamation No. 454/2005 (2005), at 5 .

87 Lower courts in this context refer to all federal and state courts at all levels in Ethiopia.

88 Ibid., at 1.
} 
structuring the justice system as a whole. It should be noted that decisions of the Cassation Division bear effects not only on the parties to the case before the Division but also to future similar cases to be brought before different levels of federal and state courts. This in turn obliges the Division to make a wide discussion and consideration before rendering its decisions. In this way, the Division gives a decision, which will bring continuity and stability in the interpretation and application of law in the country.

It also protects lower courts from spending their labor, time and energy unnecessarily by rendering decisions that might face a risk of reversal by the Cassation Division.

\subsection{Binding Interpretation of Law and Its Compatibility with Doctrine of Separation Powers}

It is an interpretation of law which is binding on lower courts under Article 2 of Proclamation No. 454/2005. In applying law, courts may face difficulties due to the fact that laws may not be clear and certain. A law may be vague because of broad words used in it, due to omission of words, printing or drafting errors or because of the occurrence of unforeseen events before the court. ${ }^{89}$ On the other hand, judges may not refuse to render a decision because of the fact that they cannot determine legal answers. They are expected to find meaning to the law in order to dispose the legal issues before them using different cannons of interpretation. ${ }^{90}$ In this respect, courts may use literal rules, golden rules and/ or other aids for interpretation such as contextual interpretation of words, the rule that general words must follow specific words; the express mention of one thing implies the exclusion of the other; ${ }^{91}$ as well as preambles and certain presumptions that help them get the meaning of laws. ${ }^{92}$

It is true that the Cassation Division renders decisions by interpreting the existing law to resolve legal issues involved in a case using one of the aforementioned rules of interpretation. Since the Division does not have the power to resolve factual issues under the Constitution, ${ }^{93}$ its decisions are limited to legal issues involved in a case. In this manner, the federal and state courts bound by the decisions of the Cassation Division should only determine the existence of similar legal issue(s) between the case before them and the binding decision of the Division. In other words, they do not concern themselves

89 Binns, supra note 34 , at 60.

90 L. Carter, Reasoning in Law, 5th edn (Longman, New York, NY, 1998), pp. 55-56.

91 D. Barker and C. Padfield, Law, 1oth edn (Made Simple, Oxford, 1998), p. 34.

$92 \quad$ Ibid., at 33-34.

93 FDRE Constitution, 1995, Article 8o (3) (a). 
with the existence of analogous facts between the case before them and the binding interpretations of the Cassation Division as the common law judges do to determine the binding nature of a case. Thus, the system of precedent introduced into the Ethiopian legal system differs from that of the common law; because in common law, lower courts must adhere to past decisions of superior courts in determining a case involving similar facts. ${ }^{94}$ On the other hand, in Ethiopia, decisions of the regular divisions of the Federal Supreme Court do not have a binding authority on lower courts. It is only the decisions of the Cassation Division that bind all federal and states' courts in the country. The final decisions of the House of Federation on the constitutional interpretation also have force of binding precedent pursuant to Article 11(1) of Proclamation No. 251/2001. Therefore, only the interpretation of law rendered by the Cassation Division of the Federal Supreme Court and constitutional interpretation made by the House of Federation have binding authority on other judicial institutions in Ethiopia.

The issue as to whether the principle introduced under Proclamation No. 454/2005 is similar with that of the common law may also be analyzed in light of the purposes for which the Proclamation is introduced. In this respect, the Proclamation shares similarity with the common law legal system since both are aimed at achieving predictability, certainty, and uniform application of laws and equal treatment of parties to the case. In the common law, the doctrine of precedent also applies to statutory interpretation. ${ }^{95}$ In this case, a precedent can be defined as '.. a decision considered as authoritative for a similar case afterward arising on a similar question of law. ${ }^{96}$ This makes the common law precedent similar to that of Ethiopia, which applies to cases with similar legal issue, but not with similar facts.

For instance, the Federal High Court of Ethiopia reached its decision based on the decision of the Cassation Division. ${ }^{97}$ Since the legal issue in the decision of the Cassation Division was similar to that of the issue before the Federal High Court, it decided by referring to the decision of the Division. In both cases, the issue that was involved was whether presumption can be raised by courts when a party did not allege them. The Cassation Division decided that courts may raise presumptions even if the party did not raise them in its pleading or

\footnotetext{
94 McLeod, supra note 20, at 121.

95 Dernbatch, supra note 24, at 200.

96 W. Mack and D. Kiser, 'Corpus Juris Secundum: A Comparative Restatement of the Entire American Law', 21 Boston University Law Review (1940), at 297.

97 Ras Hotels vs. W/ro Tehune Mezgebu, (Ethiopia) Federal High Court, Lideta Branch, 1999 E.C., Civil Case file No.31317 (unpublished).
} 
the decision is made ex parte by interpreting Article 89 of the Civil Procedure Code and Article 2024 of the Civil Code. ${ }^{98}$ The same decision was reached by the Federal High Court by referring to the conclusion already reached by the Cassation Division in resolving the legal issue.

Normally, what is called 'precedent' in common law legal system entitles the courts to make law; whereas the Cassation Division in Ethiopia only declares what the law is, and it does not make the law. Nonetheless, the common law judges also argue that they do not make law since the 'doctrine of separation of powers' prohibits them from doing so. ${ }^{99}$ According to this doctrine, each power of government is coequal to the other and operates to maintain a check and balance on usurpation of powers by the other. ${ }^{100}$ This doctrine prevents the centralization and concentration of governmental powers in the hands of one or more persons.

The FDRE Constitution generally suggests that the legislative and the executive as well as the judicial powers of the government shall exist both at the federal and state levels. ${ }^{101}$ It also states that judicial power is vested in the courts, both at the federal and state levels, ${ }^{102}$ while the legislative power is vested in the House of Peoples' Representatives on federal matters, and to the state councils on those matters falling under their jurisdictions. ${ }^{103}$

The judicial precedent declared under Proclamation No. 454/2005 may be analyzed from the perspectives of two theories in this regard: theory of judicial law making and declaratory theory. According to the judicial law making theory, which has evolved from the particular experience of the common law system, the decisions of courts involve actual law making when it is followed by other courts. ${ }^{104}$ According to this theory, judges inevitably act as legislators although it is not desirable. However, a number of common law judges deny this fact because of their fear of popular denunciation of illegal usurpation of the legislative power. ${ }^{105}$ Judicial law making was necessitated from the

98 Rental House Authority vs. Mr Bironi Atkpa, Decisions of the Cassation Division of Federal Supreme Court, Vol. 1, (1998 E.C.), Civil Case F/No.17068, at 31-40.

99 Dernbatch, supra note 24, at 36 . The doctrine of separation of powers was laid down by the French writer, Montesquieu, in the Century according to which the three government organs, i.e., legislative, executive and the judiciary are vested in different bodies or persons. See D. Lloyd, The Idea of Law (Pegium Book, London, 1991), p. 256.

100 Ibid.

101 FDRE Constitution, 1995, Article 50(2).

102 Ibid., Article 79(1) and Article 50(7).

103 Ibid., Article 55(1) and Article 50(5).

104 Reynolds, supra note 32, at 168.

105 Farnsworth, supra note 22, at 194. 
fact that judges need to decide a case in a way that their decision may fit the needs of the modern society. ${ }^{106}$ Where a law does not spell out what should be done in a case before them, judges cannot say that the law is not clear and refer the case back to the parliament. ${ }^{107}$ They try to interpret the law and apply it to the ambiguous or new situation in which they make the law under the guise of interpretation. ${ }^{108}$ This theory proposes that judges should make law in the areas where there is societal consensus. ${ }^{109}$ However, they should avoid law making in the areas where there is no consensus and a controversy is still going on as their reputation of independence and impartiality will be endangered. In addition, they may lose public confidence. ${ }^{110}$ Moreover, they must not create law in the areas where there is a reason to believe that parliament does not support such a law. ${ }^{111}$ Therefore, even the common law judges do not make law theoretically although in reality they do in certain circumstances.

On the contrary, according to the 'Declaratory Theory', law creation is not the task of the judiciary; rather, it is an exclusive task of the parliament as legislature expresses popular will through its being electorate. ${ }^{12}$ The courts are expected to apply the existing law to the case before them within existing limits of rules and principles. Furthermore, according to this theory, judges do not have ability to conduct a full-scale investigation of the need of law to the political and social practicability since they are trained only to apply law to individual cases and give judgment. Besides, they are not trained to compromise various interests. ${ }^{113}$ On the other hand, the legislator is accountable for making decisions on issues involving policy matters as the popular will is given to it. ${ }^{114}$ Sir William Blackstone, who was the advocate of the Declaratory Theory, two centuries ago wrote that: "judges are the depositories of the laws; the living oracles, who must decide in all cases of doubt, and who are bound by an oath to decide according to the law of the land...., these judicial decisions are the principal and most authoritative evidence."115

\footnotetext{
106 Ibid., at 193.

107 R. Hoffman, German Legal System and Laws, 2nd edn (Blackstone Press, London, 1996), p. 16.

108 Ibid.

109 Ibid., at 19.

110 Ibid.

111 Ibid.

112 Hoffman, supra note 107, at 193 .

113 A. Vonmehren, The Civil Law System: Cases and Materials for the Comparative Study of Law (Little, Brown, Boston, MA, 1957), p. 848.

114 F. Catalod et al., Introduction to Law and Legal Process (Wiley, New York, NY, 1965), at 186.

115 O. Hood Phillips, P. Jackson and P. Leopold, First Book of English Law, 7th edn (Sweet \& Maxwell, London, 1977), p. 210.
} 
Thus, in accordance with this theory, decisions of courts, which are binding on lower courts, are merely evidence of law rather than actually being the law. Courts only pronounce their decisions. In other words, judges are 'the mouth which pronounces the law.'116 Judges, according to Blackstone, are 'not delegated to pronounce a new law, but to maintain and expound the old law.'117 Conversely, cases that give rise to entirely new moral and social issues should be decided by the legislature, which is elected to make and change the law. ${ }^{118}$ As a result, judges have a passive function in making the existing law.

With respect to the Proclamation under analysis, for interpretation of law to exist, there must be an already enacted law that can be interpreted. A resort to interpretation is only to clarify the ambiguous and doubtful law; not to create a new law. Thus, what the Cassation Division does is declaring the law as it exists. In addition, overruling by the Cassation Division of its own previous decisions does not mean that the rule announced in the earlier decision was once the law and has now changed by the later decision. The previous decision should be taken as an erroneous decision because of judges' defect in finding the real intention of the law. Moreover, the new decision should be taken as a rectification of the earlier decision not as a new law. Hence, according to this argument, Proclamation No. 454/2005 is in line with the doctrine of 'separation of powers'.

\subsection{Effects of Judicial Overruling by the Cassation Division}

As expressly stated in Proclamation No. 454/2005, decisions of the Cassation Division are not necessarily binding on itself. ${ }^{119}$ This means, the Cassation Division can overrule its own previous decisions. Nevertheless, it is worth noting that overruling of a previous precedent often has unfortunate logical consequences if it is overruled retrospectively. In such a case, persons who have dealt with in reliance upon an earlier precedent suddenly find that the precedent upon which they had a right to rely has been changed. ${ }^{120}$ This brings a situation where the doctrine of a binding precedent operates in such a way that the outcome of a case may depend on a statement of the interpretation of law, which had not been made when the acts occurred. ${ }^{121}$ English courts

\footnotetext{
116 J. Frank, Law and The Modern Mind, 6th edn (Anchor Book, New York, NY, 1963) 35.

117 Hood Phillips, supra note 115, at 11.

118 Ibid., at 18.

119 Proclamation No. 454/2005, Article 2 (1) reads '... the Cassation Division may, however, render a different legal interpretation some other time'.

120 L.K. Garrison and C.A. Auerbach, The Legal Process (Chandler, San Francisco, CA, 1961), p. 64 .

121 Barker and Padfield, supra note 91, at 125.
} 
have always followed the practice of Retrospective Overruling, which means that the overruled case will not be applied both in the instant case and in later cases. $^{122}$ In other words, the overruling decision will be applicable to the case before the court and to future cases coming after the decision. This has been described as dog's law by Jeremy Bentham; because the parties might have relied on the previous precedent before it was overruled. However, when they come to the court, the precedent upon which they have relied is changed. It is as a dog does not know that it has done wrong until you punish him. ${ }^{123}$ This can bring injustice to the parties to the case.

The retrospective overruling, therefore, goes in line with the 'declaratory theory', which provides that judges do not make or change the law; but merely discover the existing law and declare it. ${ }^{124}$ Based on this theory, an overruled precedent will be considered as an erroneous interpretation of what the law was then and still is. On the contrary, the overruling precedent that overruled the previous precedent will be taken as the correct interpretation of what the law is. Because of the correct interpretation is the overruling precedent, it will have retrospective effect even if the case is brought to the court relying on the previous overruled precedent. ${ }^{125}$ Nevertheless, the House of Lords in the English legal system sometimes takes into account the danger of retrospectively disturbing financial arrangements and rights in property that might have been decided in the earlier case now to be overruled. ${ }^{126}$ That is, the court may not lightly overrule its previous decision if to do so will cause disturbance in legal system and bring injustice.

With a view to avoiding the injustice that can be created by retrospective overruling, the practice of prospective overruling has been developed in courts of some countries, notably, in the United States Supreme Court. ${ }^{127}$ The basic meaning of prospective overruling is to construe an earlier decision in a way so as to suit the present day needs, but in such a way that it does not create a binding effect upon the parties to the original case or other parties bound by the precedent. The use of this doctrine overrules an earlier laid down precedent with effect limited to future cases and all the events that occurred before it are bound by the old precedent itself. ${ }^{128}$ The overruling case does not apply

\footnotetext{
122 Farnsworth, supra note 22, at 170.

123 Hanks, supra note 18 , at 172.

124 Ibid.

125 Farnsworth, supra note 22, at 171.

126 Hanks, supra note 18 , at 81.

127 Ingman, supra note 23 , at 271.

128 Ibid., at 170-171.
} 
to the case before the court; rather it will only be applied to future decisions. ${ }^{129}$ Lord Nicholas has summarized the salient features of the doctrine of prospective overruling in the case of National Westminster Bank Plc. (Respondents) vs. Spectrum plus Limited and others (Appellants), as follows:

People generally conduct their affairs on the basis of what they understand the law to be. This 'retrospective' effect of a change in the law of this nature can be disruptive and seemingly unfair. 'Prospective overruling, which is sometimes described as non-retrospective overruling, is a judicial tool fashioned to mitigate these adverse consequences. It is the short hand description for court rulings on points of law which, to greater or lesser extent, are designed not to have the normal retrospective effect of judicial decisions. ${ }^{130}$

It was not until after the practice was officially sanctioned by the Us Supreme Court in Great Northern Railway Co. vs. Sunburst Oil \& Refining Co. that prospective overruling became more common. ${ }^{131}$ In Sunburst, Justice Cardozo, who had written occasionally about the notion of prospective decisionmaking, upheld the use of that practice by the Montana Supreme Court. ${ }^{132}$ Justice Cardozo wrote: "a state in defining the limits of adherence to precedent may make a choice for itself between the principle of forward operation and that of relation back."133 Sunburst gave state courts the green light to engage in prospective decision-making when and where they saw fit to do so. ${ }^{134}$

Early supporters of prospective overruling argued that the practice of announcing changes to decisional law but issuing such holdings prospectively would actually lead to greater efficiency to the common law. Chief Justice Traynor of the California Supreme Court described in his seminal article on the topic, courts often felt boxed in by the doctrine of stare decisis, which obligated a court to uphold the interests of those parties who reasonably relied

129 J. Martin, The English Legal System, 3rd edn (Cambridge University Press, Cambridge, 2002), at 33 .

130 Ibid.

131 Great Northern Ry. Co. vs. Sunburst, 287 U.s. 358 (1932).

132 Ibid., at 367.

133 A. Schaeffer, 'The Control of Sunbursts: Techniques of Prospective Overruling', $42 \mathrm{NYU}$ Law Review (1967), 631.

134 G. Ghatan, 'The Incentive Problem with Prospective Overruling: A Critique of the Practice', 45 The ABA Real Property, Trust and Estate Journal (2010), 179. 
upon an existing rule. ${ }^{135}$ As such, courts, even though acknowledging that an existing rule was often no longer justified or appropriate, continued to uphold that rule in order to protect the reliance interests at stake. ${ }^{136}$ Proponents of prospective overruling contended that by issuing changes in the law prospectively, courts could simultaneously discard bad rules while upholding any reliance interests. ${ }^{137}$ Consequently, it was argued, prospective overruling would serve to promote the development of the common law.

Prospective overruling may, however, discourage bringing lawsuits in order to get a change of the previous interpretation of law due to the fact that the party, who will be successful in securing the overruling of a previous case, will be deprived of the benefit from overruling case. ${ }^{138}$ But to avoid the fear of discouraging the litigants that seek overruling of the previous precedent, some courts in the us have applied the overruling decision to the case, which occasioned it, but have otherwise giving it only prospective effect. ${ }^{139}$ Besides, the overruling court will be applying an interpretation of law which is admitted wrong by itself since the overruling decision is not applied to the case that sought overruling. ${ }^{140}$ Despite these criticisms against the doctrine of prospective overruling, now it is recognized in the world over.

In Ethiopia, the Cassation Division tends to overrule its previous decisions retrospectively. For instance, in cases concerning effects of bigamous marriage on distribution of marital property, the Cassation Division held two conflicting positions though the facts of the cases were similar and the questions of law involved in both the cases were identical. The first case was litigated between two wives of a man (their husband) who died at the time of litigation. ${ }^{141}$ In this case, the Cassation Division decided that half of a building (common property) was to be given to the son of the deceased born to one of the disputants, and the remaining half to be divided between the two wives. The second case was also litigated between two wives of a man (husband) in which the Cassation Division decided that one of the wives was entitled to half of a

\footnotetext{
135 R.J. Traynor, 'Quo Vadis, 'Prospective Overruling: A Question of Judicial Responsibility', 28 Hastings Law Journal (1977) 533-562, at 543 .

136 Ibid., at 541.

137 Diaz vs. Eli Lilly \& Co., 302 N.E. 2d 555, 564 (Mass. 1973).

138 Ibid.

139 Ibid.

140 Ibid., at 176.

141 Sadiya Ahmed vs. Rahima Ali (Cassation Civil File No. 24625, Federal Supreme Court, Cassation Division, No. 2008). This decision is published under decisions of the Federal Supreme Court, Cassation Division, Vol. 8 at 195-197.
} 
building (which was the subject of litigation) and the remaining half should be divided between the husband and the other wife of this man. ${ }^{142}$

From the facts of the cases and decisions of the Cassation Division, one can see that the Division has held different positions at different times with respect to determining the actual share of spouses in bigamous marriage, out of the common property in the case of dissolution of bigamous marriage. In so doing the Cassation Division overruled its previous decision retrospectively since its ruling was made effective on the parties to the instant case. In overruling its own previous decision, the Division did not indicate as to whether or not the latter decision should be applied prospectively.

It is true that a decision of the Cassation Division must be adaptable to the changing circumstances. And that is the basic reason for which the Cassation Division is empowered to overrule its own previous decision when it deems it appropriate. Nevertheless, it needs to be cautious of its previous decisions and critically determine the situations and reasons that necessitate overruling of the previous it decisions. In England, the House of Lords will not refuse to follow its earlier decision merely due to the fact that the earlier decision was wrong or because it was rendered by narrow majority. ${ }^{143}$ Nor will the House consider its previous decision merely because it has caused concern among lower courts. ${ }^{144}$ It changes its decision only when it finds a material change of circumstances like when an act of parliament contains provision which contradict its previously decided cases. ${ }^{145}$ Furthermore, it reconsiders its own previous decision when it is involving some broad issue of justice or public policy. ${ }^{146}$

The Cassation Division in Ethiopia should also take similar factors into account before changing its previous interpretation of law; it should specifically consider as to whether the present circumstances can justify the overruling of its decision. The possible situations may be an amendment or repeal of a law. It is expected that a prudent overruling of a case contributes in achieving the purposes of not only establishing uniform interpretation of law but also consistency and stability in the legal system. It would be acceptable if the Cassation Division departs from its earlier decision only when it believes that doing so will dispose the cases in just manner. If the Division changes its

\footnotetext{
142 Zeinaba Kalifa vs. Kadija Siraj (Cassation Civil File No. 50489, Federal Supreme Court Cassation Division, October 04 2010). This decision is also published under Decisions of the Federal Supreme Court Cassation Division Vol. 11 at $2-5$.

143 Ingman, supra note 23.

144 Ibid.

145 Hanks, supra note 18 , at 32.

146 Dernbatch, supra note 24 , at 36.
} 
rulings arbitrarily, the purposes for which a binding precedent was introduced into the current legal framework of Ethiopia will certainly be eroded; and it will be difficult to stop those cases that flow to the Cassation Division.

Regarding the question concerning how a case will be brought to the Cassation Division for overruling', there are strange coincidences for a case to have a chance to be reconsidered. The first coincidence is where different levels of courts wrongly distinguish a binding decision of the Cassation Division and the appellate court affirms that decision. In this case, the decision might be brought to the Cassation Division for overruling since it is final and where it contains a basic error of law. Second, a litigant who has courage and persistence that he can convince the Cassation Division to change its previous position may bring his case before it.

The Proclamation under consideration also provides that an interpretation of law, which is binding is one which is decided by judges not less than five. ${ }^{147}$ This is because the more judges there are, the greater the discussion to determine the case will be. More importantly, since cases that are brought to the Cassation Division involve serious matters and require serious interpretation of the law, the number of judges must be increased compared to other divisions of courts. ${ }^{148}$ The increased number of judges is expected to bring more discussion and consideration of cases by judges as the decisions to be rendered at this stage constitute binding precedent. On the other hand, there is no a purpose of creating consensus between judges. Since the occurrence of majority of judges sitting in the adjudication is necessary and sufficient to create the binding decision of the Cassation Division, the existence of a dissenting opinion does not affect the binding nature of a case. Therefore, the minimum required number of judges refers to a number of those judges who sit for deciding a case and not the number of judges who have to concur in a decision.

\subsection{Determining the Ratio Decidendi of a Case}

In common law legal systems, lower courts follow and apply the previous case decided by the superior court when they are satisfied that the same principle of law as that of the previous case is before them for decision. ${ }^{149}$ In other words, lower courts' judges are expected to distinguish between ratio decidendi, commonly reduced to ratio or in plural rations and obiter dictum (in plural obiter dicta). ${ }^{150}$ Distinguishing between these parts of a decision involves

\footnotetext{
147 Proclamation No. 454/2005, Article 2 (1).

148 Commentary on Federal Courts' (amendment) Proclamation No. 454/2005 (2005), at 41.

149 Mcleod, supra note 20, at 141.

150 Ibid., at 133 .
} 
skill which is more of an art than science. ${ }^{151} \mathrm{~A}$ judge needs to be creative in choosing between various possibilities involved in determining the ratio and obiter dictum. ${ }^{152}$ Ratio decidendi is a Latin phrase, which means 'the reason for decision.' ${ }^{153}$ Ratio decidendi has also been given variety of definitions. For instance, Sr. Rupert Cross defined it as 'any rule of law expressly or impliedly treated by the judge as a necessary step in reaching his conclusion, having regard to the line of reasoning adopted by him.'.54 Moreover, it is also defined as 'an abstraction of a legal principle from the material facts of the case, and the decision which the judge made thereon.' ${ }^{155}$ The English courts use it as a means to bridge the gap between the doctrine of precedent and codification without tiding themselves to any one definition of ratio decidendi. ${ }^{156}$ It is only the ratio decidendi part of a judgment which is binding on the lower courts and that operates as precedent. ${ }^{157}$

There are various techniques to determine the ratio of a case suggested by different scholars. For instance, Goodhart suggests certain rules to determine the ratio. To him, the ratio decidendi of a case is not found in the reasons on which the court setting the precedent has based its decision. ${ }^{158}$ Although a judgment lacks reasons for decision, it will not lose its value of precedent as the ratio is not found in reasons. ${ }^{159}$ It is rare to find decisions of the Cassation Division in Ethiopia without reasons. However, its reasons do not bind lower courts since they are not part of the ratio of a case. Besides, Goodhart argues that the ratio is not found in the proposition of a rule set forth in a precedent setting decision. ${ }^{160}$ Moreover, he argues that we should take the facts as

$15^{1}$ Farnsworth, supra note 22, at $5^{2}$.

152 Mcleod, supra note 20, at 133.

153 C. Elliot and F. Quinn, English Legal System, 8th edn (Pearson Longman, Harlow, 2007), at 8.

154 Philips and Hudson, supra note 115, at 218.

155 Ibid.

156 Farrar and Dugdale, supra note 29, at 91.

157 Elliot and Quinn, supra note 153, at 8. The concrete decision which only binds the parties to the case should be distinguished from the abstract ratio decidendi that is binding to the cases coming after the case containing the ratio is decided. See Ingman, supra note 23, at 298 .

158 A. Goodhart, 'Determining the Ratio Decidendi of a Case', 40 Yale Law Journal (1930), 161-183.

159 Ibid.

160 Ibid. 
material and the conclusion based on these material facts as part of the ratio. ${ }^{161}$ Hence, the conclusion based on the material facts binds lower courts as it constitutes ratio decidendi. The precedent setting court reaches its conclusion based on the facts as it sees them. It chooses those facts that are considered material and based on them it reaches a conclusion. In this process it rejects those facts, which are immaterial. ${ }^{162}$ The lower courts are expected to accept the material facts taken by the precedent setting court as material facts. On the hand, they should not add or subtract any fact as material from what was set by the previous precedent setting court as material. The divorce of conclusion from material facts leads to unsound and arbitrary results. ${ }^{163}$

Additionally, Goodhart suggests certain guidelines to determine the material facts. He advises that we must assume all facts are material if the decision does not provide for the material and immaterial facts. However, facts related to the identity of a person, time, place, kind and amount must be considered as immaterial unless otherwise provided since the law is assumed to be the same for all persons at all times and at all places within the jurisdiction of a court. ${ }^{164}$ Moreover, if the previous court has expressly stated material facts, the subsequent court which applies the previous case as a material must accept the facts taken as material by the previous court since it will be difficult for later courts to consult every case to find out material facts. ${ }^{165}$ Therefore, a fact that is not considered as material by the previous court, even if it is, will not be considered as material fact by the later court. ${ }^{166}$ Besides, all facts which are expressly or impliedly stated as immaterial must be taken as they are. Facts are impliedly taken as immaterial if the courts after having stated facts generally proceed to select smaller number of facts on which it bases its conclusion. ${ }^{167}$

In general, as the ratio decidendi is a legal answer to an issue, ${ }^{168}$ lower courts in Ethiopia should be able to determine the issue in a precedent. In addition, the issue of a precedent setting decision and the case before a lower court must be similar. This is explicitly provided under Article 2 (4) of Proclamation

161 Ibid. Material facts refer to the facts that are relevant and important to the decision. See Dernbatch, supra note 24 , at 26 .

162 A. Goodhart, Essays in Jurisprudence and the Common Law (Macmillan, New York, NY, 1931), p. 6.

163 Ibid.

164 Ibid., at 11.

165 Ibid., at 13 .

166 Ibid.

167 Ibid., at 16.

168 An issue is the question that must be resolved before a case can be decided. See Dernbach, supra note 24 , at 23 . 
No. 454/2005. Courts must also identify the ratio decidendi, which requires an understanding of the case and determining what the court actually decided. ${ }^{169}$ The ratio may be stated expressly or it may be explicitly stated and found buried among a mass of obiter dicta. ${ }^{170}$ Although an expressed ratio is easy to identify, there is a hidden danger; implied ratio decidendi is harder to identify thus a resort must be taken to the action of a precedent setting court. ${ }^{171}$

In the Ethiopian context, ratio decidendi of a case is the interpretation of the law that is rendered by the Cassation Division of the Federal Supreme Court. The lower courts are bound by a decision after determining the existence of similar legal issue between the case before them and an interpretation of law made in a decision of the Cassation Division will be applied by them. If the ratio decidendi is an expressed one, it will be the conclusion that the Cassation Division reached in resolving legal issues involved in a case. If the ratio is not expressly found in the decision of the Cassation Division, lower courts should try to find it from what the Cassation Division does; not from what it says. Reasons used in the case and the issues resolved by the Cassation Division may indicate the ratio. Nevertheless, they do not have binding effects on the lower courts.

The author has conducted interviews with some judges working in lower courts in Oromia and Southern Nations, Nationalities and Peoples regional states on the extent of their awareness on how to determine the ratio decidendi of a case while deciding subsequent cases involving similar legal issues with that of the Cassation Division. The respondents unanimously indicated that they have been facing challenges in determining a ratio from dicta of a case. They said that there was no a course or training attained on how to find ratio decidendi as the common law judges do. Nevertheless, federal judges seem to be better in this regard. In a case decided by the Federal High Court, ${ }^{172}$ the judge followed the decision of the Cassation Division since the case before him contains a similar legal issue with that of the Cassation Division. ${ }^{173}$ The issue before both courts was whether a court on its own motion can raise

\footnotetext{
169 Ibid., at 21.

170 Obiter dicta or a dictum is a Latin phrase which stands for things said by the way. They are words delivered by a judge which are not essential to his decision. They cover the hypothetical situation that is explained by the judge in the course of his judgment. See Ibid.

171 Ibid.

172 The Son and Heir of Atsede Mariam Latemo, Wolde Gabre Wolde Vs. Aklilu Haile et al., Federal High Court (Ethiopia), Lideta Branch (2007) [Civil Case file No. 38331] (unpublished).

173 Gadis Arga Vs. Workantif Bekele, 'Decisions of the Cassation Division of the Federal Supreme Court' (1998 E.C.), vol. 1 [Civil Petition No. 17361], at 12-16.
} 
period of limitation provided in the Civil Procedure Code. The Cassation Division reached the conclusion that period of limitation provided in the Civil Procedure Code should be raised by courts even if it is not raised by the parties to the case, by referring to the rationale behind the Civil Procedure Code. ${ }^{174}$ The same decision was rendered by the Federal High Court by referring to the conclusion reached by the Cassation Division in resolving a similar legal issue.

\section{Conclusion}

The Ethiopian legal system is characterized by its reception of laws both from civil law and common law legal systems although the country chose to design its laws predominantly after the continental law legal system based on reasons such as its prior exposure to codification, convenience and expense. On the other hand, there are a few legislations which accorded some place to precedent at different times in Ethiopia. Particularly, precedent in its loose sense is employed under Proclamation No. 454/2005 with a view to achieving uniformity, certainty and predictability in the Ethiopian legal system. This law makes an interpretation of law rendered by the Cassation Division of Federal Supreme Court, no less than five judges, binding on all courts in the country. To interpret a law, there must be a law to be interpreted. Thus rendering a binding precedent does not mean making a law which is a prerogative of the legislature. In this manner, since the Cassation Division declares what the law is, its binding decisions does not affect the doctrine of separation of powers, which is also enshrined under the FDRE Constitution.

Furthermore, a decision of the Cassation Division must be adaptable to the changing circumstances. For the most part, the Cassation Division should take the account of whether or not circumstances justify the overruling of its previous decision. The possible situations for this may be an amendment or repeal of law. Besides, the Cassation Division should only depart from its earlier decision when it believes that doing so will dispose the cases in just manner. Unless it overrules its decisions only in very limited circumstances, the purposes for which the binding precedent was introduced into the legal system could be eroded; and it will also be difficult to stop those cases flowing to the Cassation Division itself. Moreover, one of the unfortunate logical consequences of an overruling of a previous precedent is its retrospective effect. In such a case, persons who have dealt in reliance upon an earlier precedent suddenly find that the precedent upon which they had a right to rely has been changed. This

174 Ibid. 
brings a situation where the doctrine of a binding precedent operates in such a way that the outcome of the case may depend on a statement of the interpretation of law, which had not been made when the acts occurred. To avoid the adverse consequences of retrospective overruling, therefore, the Cassation Division should overrule its previous decisions prospectively so that its overruling decision will be applied to future cases only.

Ratio decidendi is a part of previously decided case which later judges regard as binding on them due to the fact that it embodies a legal rule, which justifies a particular decision. On the other hand, obiter dicta does not have binding authority. Distinguishing between these parts of a decision involves skill which is more of an art than science. A judge needs to be creative in choosing between various possibilities involved in determining the ratio and obiter dictum. Without some sort of exposure through trainings and experience, judges in Ethiopia may face a difficulty in determining the ratio decidendi from the dicta of a case. 